\section{Communication}

[Comunicação]
E.P.F. Souto

https://orcid.org/0000-0002-0401-5272 C.R.M. Pessoa https://orcid.org/0000-0003-0231-5092 A.F.A. Pessoa https://orcid.org/0000-0002-9541-6273 M.E. Trost

https://orcid.org/0000-0002-7255-3929 G.D. Kommer

org/0000-0002-2255-3015 F.R. Correa
https://orcid.org/0000-0001-5738-7785 A.F.M. Dantas

https://orcid.org/0000-0002-6123-2273

\title{
Esophageal pythiosis in an ostrich (Struthio camelus)
}

\author{
[Ptiose Esofágica em avestrus (Struthio camelus)] \\ E.P.F. Souto ${ }^{1}$, C.R.M. Pessoa ${ }^{1}$, A.F.A. Pessoa ${ }^{1}$, M.E. Trost ${ }^{2}$, \\ G.D. Kommers ${ }^{2}$, F.R. Correa $^{3}$, A.F.M. Dantas ${ }^{1}$ \\ ${ }^{1}$ Universidade Federal de Campina Grande - Patos, PB \\ ${ }^{2}$ Universidade Federal de Santa Maria - Santa Maria, RS \\ ${ }^{3}$ National Institute of Agricultural Research - La Estanzuela - Colonia, Uruguay
}

Pythiosis is a chronic inflammatory disease caused by the oomycete Pythium insidiosum (kingdom Stramenopila, family Pythiaceae), which occurs mainly in tropical, subtropical and temperate regions and can affect several animal species (Chaffin et al., 1995). In domestic mammals, this disease are well documented in horses, dogs, cats, sheep and cattle (Martins et al., 2012; Rakich et al., 2005; Tabosa et al., 2004); and occasionally reported in other species, such as goat (Carmo et al., 2015) and donkey (Maia et al., 2016). In wild mammals, pythiosis was reported in camels, spectacled bears, Bengal tiger and American jaguar (Gaastra et al., 2010).

In avian species, there is a single record of the cutaneous form in a white-faced ibis (Plegadis chihi) (Pesavento et al., 2008). The present report describes a case of esophageal pythiosis in an ostrich (Struthio camelus), which to our knowledge is the first characterization of the disease in this species.

Epidemiological data, clinical signs and pathological findings were reviewed from the reports of the Animal Pathology Laboratory of the Federal University of Campina Grande, Patos, Paraiba, Brazil. An anesthetic protocol for the surgical procedure was performed with xylazine $2 \%(0,7 \mathrm{mg} / \mathrm{kg}$ IV) and subcutaneous infiltration of local anesthesia with $30 \mathrm{~mL}$ of $2 \%$ lidocaine with vasoconstrictor.

Tissue samples were fixed in $10 \%$ neutral buffered formalin, processed routinely, embedded in paraffin wax and cut into $3 \mu \mathrm{m}$ sections. The sections were stained with hematoxylin and eosin (HE), periodic acidSchiff (PAS) and Grocott's methenamine silver stain (GMS).

Immunohistochemistry (IHC) was performed for identification of the agent. The IHC protocol was performed according to Martins et al. (2012) using a polyclonal antibody (anti-P. insidiosum) produced in rabbits (Gabriel et al., 2008). Briefly, the primary antibody at a dilution of 1 in 1,000 was detected by use of streptavidin-biotinalkaline phosphatase complex and labelling was 'visualized' with Permanent Red (Dako, Glostrup, Denmark) as a substrate chromogen. We analyzed a previously confirmed positive control (equine cutaneous pythiosis) simultaneously with the tested samples. The negative control included tissue samples incubated with phosphate buffered saline instead of primary antibody.

\section{RESULTS}

In a farm located in the semiarid region of Paraiba's state, northeastern Brazil, eight ostriches were raised, separated in couples, in four paddocks of a half hectare each. They were supplemented with chopped barbary fig (Opuntia ficus-indica) and wheat bran. The drinking water came from a pond located in a neighboring paddock, where it was pumped through pipes into a tank and then distributed to drinkers. In previous years, nine horses from the farm that consumed water and fed on aquatic plants in this pond developed cutaneous pythiosis.

Recebido em 13 de março de 2018

Aceito em 9 de novembro de 2018

E-mail: erickplatini@gmail.com 
A 2-year-old female red-necked ostrich presented with hyporexia for one week. On clinical examination, the bird showed dysphagia and partial esophageal obstruction by a mass in the middle third of the esophagus. Surgery was successfully performed and the bird recovered without complications. A transmural thickening area, measuring approximately $10 \times 5 \times 3 \mathrm{~cm}$, and partially obstructing the esophageal lumen was found. The mucosa was blackened and friable and showed discrete ulcerations. The area was removed and, on cut surfaces, there were irregular pale areas extending through the wall from the mucosa to the muscular layer and, in some areas, to the adventitia (Figure 1A).

Histologically, there was a focally extensive area of necrosis extending from the mucosa to the muscular layer and, in some sections, to the adventitia (Figure 1B). Surrounding the necrotic area were heterophils, eosinophils, macrophages and lymphocytes, associated with fibroplasia and neovascularization. Numerous longitudinal and cross sections of negatively stained hyphae, in HE-stained sections, were detected throughout the inflammatory and necrotic areas. Additionally, hyphal invasion of blood vessel walls, hemorrhage, congestion and presence of granulocytes in the lamina propria were observed.

In histological sections stained by PAS the walls of the hyphae were weakly stained, but when impregnated with GMS the hyphae were intensely stained and characterized by tubular structures with almost parallel walls, sparsely septate and measuring approximately $3-8 \mu \mathrm{m}$ in diameter (Figure 1C). The hyphae revealed strong immunolabelling of the cytoplasm and wall in red for $P$. insidiosum (Figure 1D).

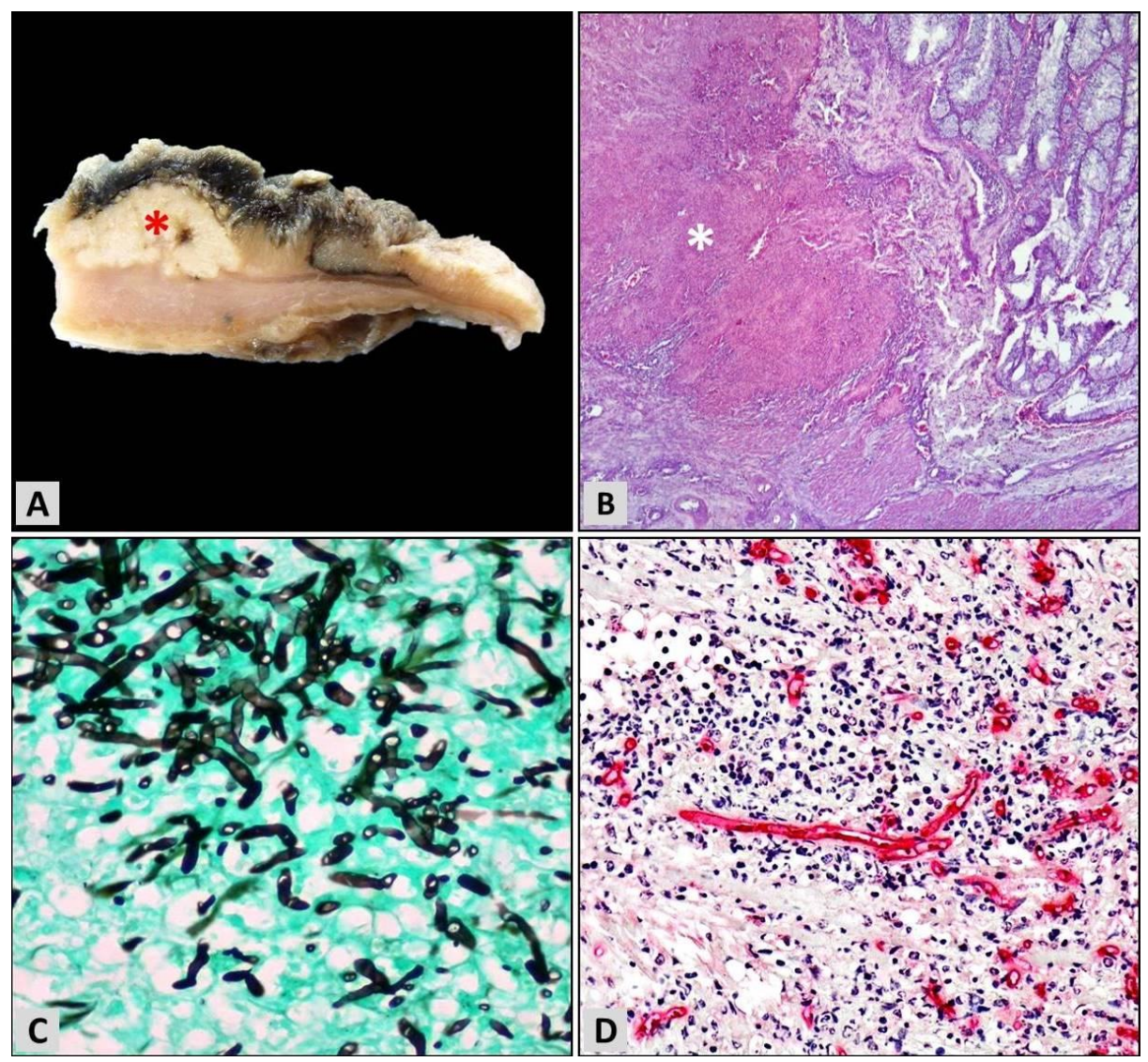

Figure 1. Esophageal pythiosis in an ostrich (Struthio camelus). A) Cross section of the esophagus showing a thickened and irregular pale area (asterisk) extending through the mucosa to the muscular layer. B) Focally extensive area of necrosis (asterisk) extending from the submucosa to the muscular layer. HE. Bar, $100 \mu \mathrm{m}$. C) Numerous intralesional hyphae intensely impregnated in black. GMS. Bar, $20 \mu \mathrm{m}$. D) IHC showing strong immunolabelling of the hyphae in red. Bar, $20 \mu \mathrm{m}$. 


\section{DISCUSSION}

The diagnosis was based on the epidemiological, clinical, anatomopathological, histochemical and immunohistochemical findings, which were consistent with esophageal infection by $P$. insidiosum. In the farm where the ostriches were raised, there were nine cases of cutaneous pythiosis in horses previously diagnosed. These horses had unrestricted access to the local pond, which also was used as the only drinking water source for the ostriches. Thus, it is likely that the infection occurred by intake of water contaminated by the mobile zoospores of $P$. insidiosum.

The pathogenesis of infection in digestive tract is uncertain. It is unclear if pre-existing mucosal lesions are essential for the penetration of $P$. insidiosum zoospores (Mendoza et al., 1996; Grooters et al., 2003). However, the habit of ostriches ingesting foreign objects, such as rocks and grains of sand, and fibrous or rough foods are important causes of traumatic lesions in their digestive tract (Carrer et al., 2004). In this case, the ostrich was supplemented with chopped barbary fig, a species of cactus covered by sharp spines, which could have damaged the esophageal mucosa and favoured the penetration of the agent.

Injury to the digestive tract by $P$. insidiosum has been described previously in dogs (Frade et al., 2017), horses (Bezerra Júnior et al., 2010), cats (Rakich et al., 2005) and lambs (Pessoa et al., 2012). In dogs, this is the main presentation of the disease and the intestinal segments are particularly affected, with clinical signs of vomiting, weight loss, intermittent diarrhea, hematochezia and palpable masses in the abdomen (Frade et al., 2017). In this case was affected the esophagus (upper digestive tract) and the clinical signs consequently reflected the partial luminal stenosis.

The esophageal lesion was characterized by a pyogranulomatous reaction with infiltration mainly by heterophils, eosinophils, lymphocytes, and macrophages, and it is similar to gastrointestinal pythiosis in other species (Frade et al., 2017; Martins et al., 2012; Pessoa et al., 2012).

The histochemical staining was an important auxiliary tool in the recognition of the etiologic agent. The PAS stain is known to promote weak staining of oomycetes such as $P$. insidiosum, allowing rule out of most fungal organisms, which stain strongly; while GMS stain allows clear visualization of the histomorphological characteristics of the agent (Grooters et al., 2003). Nevertheless, these histomorphological characteristics are not distinctive and important differential diagnoses may include Zygomycetes and the oomycete Lagenidium spp (Grooters et $a l ., 2003$ ). Identification of the agent should be confirmed by immunohistochemical techniques.

In conclusion, $P$. insidiosum affects the ostriches digestive tract and should be considered as a cause of dysphagia. We believe this paper represents the first characterization of the disease in this species.

\section{ACKNOWLEDGMENT}

To the National Research Council (CNPq) for project financing: Universal Edict (Grant 474602/2012-5) and Productivity Scholarship (Grant 302082/2014-0).

Keywords: avian diseases, esophagitis, hyphae

\section{RESUMO}

Uma avestruz-do-pescoço-vermelho, com dois anos de idade, apresentava um nódulo no terço médio do esôfago e foi submetida a procedimento cirúrgico. Histologicamente, observou-se uma área focalmente extensa de necrose estendendo-se da túnica mucosa à muscular, e, em algumas secções, à túnica adventícia. Circundando a área de necrose, observou-se uma reação inflamatória composta principalmente por granulócitos e macrófagos, associada à fibroplasia e neovascularização. Em meio às áreas de necrose e inflamação, verificavam-se numerosas imagens negativas de hifas em seções longitudinais e transversais, melhor apreciadas pela coloração de metenamina nitrato de prata de Grocott. O diagnóstico definitivo de infecção por Pythium insidiosum foi confirmado por imuno-histoquímica. A avestruz recebia água para consumo de um lago localizado em uma área de pastagem, no qual alguns cavalos haviam desenvolvido pitiose cutânea anteriormente.

Palavras-chave: doença de ave, esofagite, hifas 


\section{REFERENCES}

BEZERRA JÚNIOR, P.S.; PEDROSO, P.M.O.; PAVARINI, S.P. et al. Equine intestinal pythiosis in Southern Brazil. Arq. Bras. Med. Vet. Zoot., v.62, p.481-483, 2010.

CARMO, P.M.S.; PORTELA, R.A.; SILVA, T.R. et al. Cutaneous pythiosis in a goat. $J$. Comp. Pathol., v.152, p.103-105, 2015.

CARRER, C.C.; ELMOR, R.A.; KORNFELD, M.E. A criação do avestruz. In: (Eds.). Guia completo de A a Z. Ostrich do Brasil. Pirassununga: São Paulo, 2004. p.100-112.

CHAFFIN, M.K.; SCHUMACHER, J.; MCMULLAN, W.C. Cutaneous pythiosis in the horse. Vet. Clin. N. Am. Equine Pract., v.11, p.91-103, 1995.

FRADE, M.T.S.; DINIZ, P.V.N.; OLINDA, R.G. et al. Pitiose em cães na região semiárida do Nordeste, Brasil. Pesqui. Vet. Bras., v.37, p.485490, 2017.

GABRIEL, A.L.; KOMMERS, G.D.; TROST, M.E. et al. Surto de pitiose cutânea em bovinos. Pesqui. Vet. Bras., v.28, p.583-587, 2008.

GAASTRA, W.; LIPMAN, L.J.A.; DE COCK, A.W.A.M. et al. Pythium insidiosum: an overview. Vet. Microbiol., v.146, p.1-16, 2010.

GROOTERS, A.M. Pythiosis, lagenidiosis, and zygomycosis in small animals. Vet. Clin. N. Am. Small Anim. Pract., v.33, p.695-720, 2003.
MAIA, L.A.; OLINDA, R.G.; ARAUJO, T.F. et al. Cutaneous pythiosis in a donkey (Equus asinus) in Brazil. J. Vet. Diagn. Invest., v.10, p.33-35, 2016.

MARTINS, T.B.; KOMMERS, G.D.; TROST, M.E. et al. A comparative study of the histopathology and immunohistochemistry of pythiosis in horses, dogs and cattle. J. Comp. Pathol., v.146, p.122-131, 2012.

MENDOZA, L.; AJELLO, L.; MCGINNIS, M.R. Infections caused by the omycetous pathogen Pythium insidiosum. J. Med. Mycol., v.6, p.151-164, 1996.

PESAVENTO, P.A.; BARR, B.; RIGGS, S.M. et al. Cutaneous pythiosis in a nestling white-faced ibis. Vet. Pathol., v.45, p.538-541, 2008.

PESSOA, C.R.M.; RIET-CORREA, F.; PIMENTEL, L. et al. Pythiosis of the digestive tract in sheep. J. Vet. Diagn. Invest., v.24, p.1133-1136, 2012.

RAKICH, P.M.; GROOTERS, A.M.; TANG, K.N. Gastrointestinal pythiosis in two cats. $J$. Vet. Diagn. Invest., v.1, p.262-269, 2005.

TABOSA, I.M.; RIET-CORREA, F.; NOBRE, V.M. et al. Outbreaks of pythiosis in two flocks of sheep in northeastern Brazil. Vet. Pathol., v.41, p.412-415, 2004. 